\title{
E-Banking: Status, Implementation, Challenges,Opportunities
}

\author{
Farshad havasi ${ }^{1}$, Fattaneh Alizadeh Meshkany ${ }^{2}$, Reza Hashemi $^{3}$ \\ ${ }^{1}$ Master Student of Business Management, Kermanshah Branch, Islamic Azad University, Kermanshah, Iran \\ ${ }^{2}$ Faculty member Department of Business Management, South Thran Branch, Islamic Azad University, Thran, \\ Iran \\ ${ }^{3}$ Faculty member Department of Science, Razi University, Kermanshah, Iran
}

\begin{abstract}
Increased competition, changing business environments, globalization and the advancement of Information and Communications Technology are the important factors that have forced Banking and Financial services to change. Demand for financial services is changing rapidly and customer behavior regarding these services is also adapting rapidly.Electronic banking is the wave of the future. It provides enormous benefits to consumers in terms of the ease and cost of transactions. But it also poses new challenges for country authorities in regulating and supervising the financial system and in designing and implementing macroeconomic policy.The major challenges that Electronic banking is facing is the security variability, lack of knowledge of end users, failure of bank transitions, user interface etc. In this paper we also conclude that what factors should be enhanced to improve Electronic banking.
\end{abstract}

Key Words: Status, Implementation, Challenges, Opportunities

Accepted Date: 11 Mar 2013

\section{Introduction}

Information technology development and communication network, have opened a new horizon in front of markets and financial section. New processing methods date interchange and making data base, all, have caused efficiency improvement, speeding connection \& decreasing costs in the financial in statutes. These are main factors in the field of financial - competitive markets and changed the attitude toward them (manuchehri, 1384). On the other hand, fast development of information technology networks and then banking services, figural and semi - figural financial institutions, private banks, and so... have made a high competitive condition. Nature and method of new electronic banking, through the change in their life, has changed the customer's expectations (hamidzade\&etal, 1386).

Customers expect new and effective techniques and services, so, a bank is successful that be able to attract more sources. Electronic banking is the only choice to achieve the goal of development (Aamade\&etal 1388). Electronic banking is the acme of informatics technology usage, to omit time and place limitations.

During the past decades, money flow factors were: Bank working hours, number and place of branches, but, now electronic banking. Let's define Electronic banking, basically, Electronic banking, refers to such facilities for customers to access banking services safely, without physically presentation (P. kasturivatna, 2004)

Electronic banking has many advantages and interesting diversities including more number of customers, services in higher quality and lower price, preservation and enhancement of share inmarket, unlimited space for market, concentration in new distribution, making competitionbetween commercial brands, concentration on expenses and improvement of revenue, providingextensive services, improvement in management system, decreasing the expenses of contractions,close intra banking connection, controlling ecological pollution, etc.

There are several major challenges and issues facing the e-banking industry today.First, and perhaps most important is the security concern (Feinmanet al., 1999; FinancialServices Security Lab Background, 2001).

Customers are certainly concerned of givingtheir bank account number online or paying an invoice through internet. Anotherchallenge facing e-banking industry and the e-business in general is the quality ofdelivery service - including both delivery speed (i.e., short advance time required inordering) and delivery reliability (i.e., delivery of items/services on time) (Furstet al., 2000), which caused many e-business failures in the earlier dot.com era. Limited onlinepayment options have resulted in many customers to drop out in the last stage of thepurchasing process due to dissatisfaction and inconvenience (Furash, 1994). Finally, theissue of customer unfamiliarity with the internet, which is prominent among seniorcitizens, has recently caught some attention, because these customers believe that they areleft at a disadvantageous position and become very reluctant in doing business online. Based on the early e-banking experience, it has been predicted that to be successful in long term, the operations of an e-business must compete differently fromthose traditional business counterparts. That is, the strategic positioning decision of ane-banking operation must establish its own unique 
competitive advantages over itstraditional business competitors and sustain its customers on a regular basis (Klinkerman,2000; 2001). Currently there are two different approaches in the e-banking industry: aseparate (from its traditional office) internet e-bank (i.e., virtual bank) with alltransactions being transacted online, or to add an online banking section to the servicesalready being offered by its major bank office (Hackett, 2000; Hughes, 2003; Sweeneyand Morrison, 2004). Both approaches have advantages and issues to be addressed inpractice (Beckieret al., 2000; Gulatti and Garino, 2000).

\section{Literature Survey}

Electronic banking is defined as the provision of banking services to customers through the internet (Daniel, 1999). Services offered by banks using the internet include: Mobile banking (m banking), video banking, fund transfers, e-payments and ATM cards. Of all e-banking services on offer, However, technological advancements keeps broadening the frontier of possibilities in all human endeavours and thus more e-banking services are being developed and introduced. This amongst other reason has perhaps informed the large number of literature and research into the underlying determinants of acceptance of electronic banking by customers. It is generally accepted that increases in income and education have been found to be positively related to the adoption of an innovation ( Lee and Lee, 2000; Lee et al., 2002). These studies show that people of higher education and income have a higher technology adoption rate than those of lower income and education. Kamakodi et al (2008) amongst others believe this to be true for e-banking as well. Studies have also shown the effects of demographic characteristics on technology acceptance. In the works of Gefen\& Straub (1997), it was found that gender has a direct influence on adoption of technology with men and women having different rates of computer technologies adoption. Putrevu (2002) suggests that difference in information processing exists between men and women and as such both genders will have different rate of technology acceptance. Zeithaml and Gilly (1987) also opined the existence of a positive relationship between education, income, and exposure to mass communication and the adoption of Electronic Funds Transfer (EFT) with the latter as the dependent variable. The study also showed that this relationship was greater for younger than for older consumers. Lee et al. (2002) discovered the older the adopters the lower the rate of technology adoption. And in the words of Hogarth et al (2008), 'Increases in income and education also elicit a positive effect on adoption, regardless of the technology. On the other hand, the impacts of other demographic characteristics on adoption are less clear'.

Empirical studies from the consumer side of ebanking have focussed on the quality of customers on the utilisation of current e-banking services (Hitt and Frei, 2002), and another recent one examining the customer attitudes towards e-banking and concluding that online banking marketing will gain importance at a faster rate in the coming years (Kaynak and Harcar, 2005). Other new e-banking serviceshave targeted mortgage lending, consumer lending, and small business loan products. As an Integral part of the e-business, the e-banking industry has been growing at a rapid pace, to help banks cut costs, increase revenue, and become more convenient for customers (Halperin, 2001). A recent research even investigated the impact of e-banking on building inter-firm relationships within 200 Australian banks and showed that an effective e-banking may enhance inter-firm relationships through improved traditional communications (Rao, 2004).

A bank must make in the development of e-banking services. Top of its priority is to address the bank's privacy policy and procedures - which will be scrutinised by the related governmental regulatory bodies.

Second on the preference list is about e-banking disclosure policies to fully define the bank's responsibilities and liabilities and also those of its customers regarding the e-banking service. Next decision is related to the design of the package of e-banking services to be offered to its customers. Those e-banking services could be ranging from a standard package, or a more complex service offerings (including bond purchases, wire transfers, and e-payments), and even a whole package (including tax payments, cash orders, bill payment, direct payment, new account enrolments, and commercial cash management). Finally, the development of e-banking service has encouraged the adoption of a decentralised approach to give banks more needed flexibility to

distribute online access to a much larger number of employees and potential customers.

( Hise, 2000; Beckett, 2000).

A previous study in Joze, Julie \& Angela (2002) showedthat that the major benefits of e-commerce adoption notanticipated by the sector are business, efficiency, improvedimage, competitive advantage, increased automationof processes and increased business turnover. Also, thekey challenges identified for the sector are the costs ofthe technology, the lack of knowledge of e-commerce,managing the change, budgeting and issues associated withlinking back end systems. They did not consider securetransactions as a major challenge for the sector; in contrastthey were considered one of the success factors.Pohjola (2002) also showed that the contribution of theuse of information communication technology to growth ofoutput in the Finnish market sector has increased from 0.3 percentage points in early 1990s to 0.7 points in late 1990 s.Similarly, research conducted in Estonia (Aarma andVensel, 2001), bank customers use bank office services onaverage 1.235 times per month, and wait in queue in bankoffice on average for 0.134 hours. Simple calculation shows, that making 
payments via E-banking facilities (for instanceusing Internet bank) rather than in the bank offices createoverall economy savings in the amount of $0.93 \%$ of GDP(Average distance to nearest bank office is $4.14 \mathrm{~km}$ (Aarmaand Vensel, 2001), which takes approximately 0.21 hoursto travel. (BankAway, 2001; Gur_u, 2002) also consideredthe benefit from the customer point of view that there isa reduction in costs of accessing and using the bankingservices, increased comfort and timesaving - transactionscan be made 24 hours a day without requiring the physicalinteraction with the bank, quick and continuous access toinformation and corporations will have easier access toinformation as, they can check on multiple accounts at theclick of a button, better cash managementAccording to a survey by Booz, Allen \& Hamilton(1996), an estimated cost providing the routine businessof a full service branch in USA is \$1.07 per transaction, as compared to 54 cents for telephone banking, 27 centsfor ATM (Automatic Teller Machine) banking and 1.5cents for internet banking (Nathan 1999; Pyun et al.,2002). In Nordea Bank, Finland, one online transactioncosts the bank an average of just 11 cents, comparedto $\$ 1$ for a transaction in the branch (Echikson, 2001).

Average payment in internet bank or via direct debit cost 4 times less, than payment in branch. On actual cost side (or cost side from the bank point of view), average direct debit payment cost 16 times less and payment in internet bank 7 times less, than payment in branch. Amrit (2007) however submitted that risk management, infrastructure development and policy formulation are the three major challenges of E-banking . Technological problems like connect break in service while withdrawing cash from ATM and poor mobile service. He also considered that an adequate level of infrastructure and human capacity building are required before banks adopt the full-fledged E-banking. But Mohammad (2009) summarized the major risk of e-banking as operational risks (e.g. security risks, system design, implementation and maintenance risks); customer misuse of products and services risks; legal risks (e.g. without proper legal support, money laundering may be influenced); strategic risks; reputation risks (e.g. in case the bank fails to provide secure and trouble free ebanking services, this will cause reputation risk); credit risks; market risks; and liquidity risks

AlirezaMoghali (1386) considers the importance of electronic banking and discusses itsadvantages in an article titled "the acceptance of electronic banking in customers in Shiraz." Theeducation of customers is of real importance in this regard as well. AtousaGoudaezi and VahidZobeidi (1387) discussed the influence of electronic banking in profits made by the bankingsystem. HamideAmade and Mahmoud Jafarpour (1388) studied the 4 groups of obstacles in aresearch titled "the study of obstacles and strategies to improve electronic banking in perspectiveof Iran 1404." These obstacles include cultural-social, management, financial and technical onesand the first two are accepted and the second two are rejected at the end of the study. In anotherarticle written by MohammadrezaHamidizadeh and ManijeGhareche and AbdolhamidAbdolbaghi (1386) some other factors such as decrease in service expenses, managers and expertsare taken into account as influencing on electronic banking system. They also introduce factorslike lack of Internet foundation and lack of experts as the important challenges in the field ofelectronic banking.

Of their income from nontraditional activities comparing to banks without e-banking operations (Stamoulis, 2000). In addition, the e-banking option will in fact as an effective way to reduce the costs of operations for the financial institutions. But in practice, larger banks located in a centralised urban area tend to have the greatest incentive to adopt e-banking services, while in comparison, smaller community banks tend to have a high initial technological cost in developing e-banking services (Treadwell, 2001). For instance, a larger city bank (in Boston) had spent over $\$ 3$ millions on the effort to offer the following e-banking services: customer pay bills, transfer funds and check account balances online, along with marketing campaign including print work, radio spots, out-of-home executions, direct mail, online advertising and in-branch merchandising (Flass, 2000). Looking forward, most small banks are motivated to develop e-banking services for potential future cost savings and

While e-banking has been a fast-growing industry among all types of e-business, it has argued that somehow its positive impact was overestimated in some claims and its limit was underestimated more often (Wolfe, 2004). With the statistics of about $80 \%$ of all banking transactions are currently still conducted at bank branches, while only $13 \%$ are performed through the internet and another $12 \%$ via the phone. But the same study predicts that the e-banking services will be very likely to dominate consumer choice in the near future (Wolfe, 2004). Risk in the banking industry has always existed, but providing e-banking services actually has increased or modified some traditional risks associated with banking activities, in particular strategic, operational, legal and reputationrisks, thereby influencing the overall risk profile of banking (Duran, 2001). As a result, the Basel Committee established the Basel Guidelines consisting out of 14 principles for banks to manage the risk of e-banking (Rehm, 2003). It has been recognised that to make e-banking a success, it must be not through it being a resource of income, but rather for its money saving ability and a port of interaction with customers (Wade, 2003). One of the essential ingredients for a successful e-banking operation is therefore simplicity anduser-friendliness in the financial planning and management process (Hamisah, 2003).

\section{Objective of the Study}


-To understand the issue E-Banking and its evolution.

-To recommend the government role on establishing E-Banking.

- To highlight the challenges of E-Banking.

- To suggest policy implications to make E-Banking more effective.

\section{Benefits Of Electronic Banking}

Banks just like other businesses are tuning to information technology to improve business efficiency, service quality and attract new customers. Al-Sukkar and Hasan (2005) aver that the most important factors encouraging consumers to use online banking are lower fees followed by reducing paper work and human error.

Subsequently electronic channels can lead to lower transaction costs which are very competitive (Claessens and Kliengbiel, 2000). Kiang et al (2000) is of the view that disputes can be minimised between the employees as there is a clear flow of processes.Conducting business outside the normal branch working hours has also been a factor that has been considered convenient for bankers. inexpensive access to the bank 24 hours a day and seven days a week. Increased availability and accessibility of more self service distribution channels help bank administration in reducing the expensive branch network and associated staff overheads. A reduction in the percentage of customers visiting the banks with an increase in alternative channels of distribution will also minimise the queues in branches (Thornton and White, 2001). According to Thornton and White (2001) this ultimately leads to improved customer satisfaction.Jayawardhena and Foley (2000) observe that electronic banking increases competition within the banking system and also from non-bank financial institutions.

Electronic banking also increases the power of the customer to make price comparisons across suppliers quickly and easily and as a consequence this pushes prices and margins downward. Kerem (2003) observes that banks are responding to electronic banking differently and that those which see electronic banking as a complement and substitute to the traditional channels achieved better communication and interactivity with the customers.

Other benefits that have accrued because of the adoption of electronic banking in developed countries include the ability to attract new customers and widening the customer database, improving bank marketing and communication, and having the ability to retain high profit customers (Al-Sukkar and Hasan, 2005). Lack of user-friendly technology, customer demand, high initial set-up costs, redundancy of existing high-cost legacy systems, economic instability, regulatory controls and lack of suitable skills have been highlighted as some of the most important issues delaying the adoption or diffusion of electronic banking (Chang, 2003).

\section{The critical success factors of e-banking}

In setting up e-banking services commercial banks must make sure that the systems are well integrated and more convenient to the customer. Consumers do not want to navigate from website to website to access services, web services have to be convenient, easier to use, and less expensive than the alternative traditional banking to win the loyalty of customers (Cronin, 1998 cited in Shah et al, 2009). The interactive nature of ebanking brings more understanding of the customer. According to Franco and Klein (1999) the data gathered about customer-bank interaction can be analysed using mining techniques and this marketing decision support capability will ultimately determine the success of the bank"s electronic banking services.

Orr (2004) sees provision of a pleasant experience on the delivery channels as one of the key requirements in adopting successful e-banking services. Franco and Klein (2009) stress the importance of upgrading technological infrastructure to bring it up to the speed with internet trade.

\section{Limitations of E-Banking}

In spite of the gross benefit received from e-banking, other factors have been hindering it from functioning as it should. Some of these factors include problems of security. The security and privacy aspects are major issue incase of e-banking transaction. Various sites are not properly locked, to ensure whether customer"s money is safe in the cyber world or not especially in these times of cyber fraud. Also high cost of setting up is also an issue in the implementation of e-banking. The infrastructural cost of providing e-banking facility is very high. The banks not only have to automate front-end services but also back office services, which involve high cost in terms of equipments and other computerized and communication facilities. There is also lack of awareness of the e-banking services to most customers. Another great hindrance is lack of awareness because, effective and wide media efforts in publishing Internet banking need to be emphasized. Lack of computerization is also a great hindering factor. Lack of computerization and low density of telephone lines is also a bottleneck for online banking.

\section{International Trends in E-banking}


Though data on internet banking are scarce, and differencesin definitions make cross-country comparisons difficult, a preliminaryanalysis by Nsouli and Schaechter from InternationalMonetary Fund (IMF) shows that internet banking is particularlywidespread in Austria, Korea, the Scandinavian countries,Singapore, Spain, and Switzerland, where more than 75 per centof all banks offer such services (Nsouli and Schaechter 2002).

The Scandinavian countries have the largest number of internetusers, with up to one-third of bank customers in Finland andSweden taking advantage of e-banking.In the US, Internet banking is still concentrated in the largestbanks. While most US consumers have accounts with banks thatoffer internet services, only about 6 per cent of them use theseservices.

As of today, most banks have combined the new electronicdelivery channels with traditional brick and mortar branches, buta few that have emerged offer their products and services only

Through electronic distribution channels. These 'virtual' or 'internetonly' banks do not have a branch network but might have aphysical presence, for example, an administrative office or nonbranchfacilities like ATMs. The US has about 30 virtual banks;

Asia has two, launched in 2000 and 2001; and the European Union has several, either as separately licensed entities or assubsidiaries or branches of brick and mortar banks.In developing economies, however, the spread of e-bankingis much limited. Globally speaking, internet usage only startsto take off once the average purchasing power of citizens exceedsUS $\$ 10,000$, although of course this is also affected by thedistribution of income. But there are some emerging economies, which have higher internet usage than their incomes wouldsuggest such as Korea. An important factor that affects usageis the cost of connecting to the internet, which varies widely.

\section{The reasons of E-banking development}

The properties of the Internet make it an ideal medium for delivery of banking products and services. Both financial entities and customers of financial products and services are benefiting from the spread of online banking services (Guerrero et al., 2007). Some banks also allow services such as stock market transactions, and the submission of standardized accounting payment files for bank transfers to third parties (Claessens et al., 2002). The number of E-banking services to customers continues to grow and the Internet offers enormous opportunities for banks, and other financial services to fundamentally reshape their organizations (US web corporation, 2001). Banks can generate revenue through increased account, access fees and benefit from promotional opportunity to cross-sell products such as credit cards and loans

As we saw, E-banking offers many benefits to banks as well as to customers. One of the main reasons for the growth of E-banking is that, if handled correctly, it can significantly lower the cost of delivering products and services. Costs of transactions in E-banking can be as low as a tenth of the cost of banking through conventional means. So, we can find two fundamental reasons underlying E-banking development and diffusion. First, banks get notable cost savings by offering E-banking services. It has been proved that Ebanking channel is the cheapest delivery channel for banking products once established (Robinson, 2000; Giglio, 2002). Second, banks have reduced their branch networks and downsized the number of service staff, which has paved the way to self-service channels as quite many customers felt that branch banking took too much time and effort (Karjaluoto et al., 2003). Therefore, time and cost savings and freedom from place and staff have been found the main reasons underlying E-banking acceptance.

\section{E-Banking Opportunity and Challenges}

Timmers (2000) supports this view, highlighting the key features of the Internet - such as 24

hour availability, almost immediate access, and the absence of physical borders. Indeed, theInternet has been one of the key drivers in promoting E-Commerce in the banking sector(Jeevan, 2000). The opportunities for banks in the Internet arena are varied (Stamoulis, 2000).

Despite this plethora of opportunities, threats to the e-banks abound. One major threat tobanks is the "Internet only" virtual banks. With US\$ 2 million, one can set up a fully-functional,Internet Only bank and provide payment services on the Internet.

The Internet banks serve also as gateways offering identification and authorization services to a number of third party service providers. There are user-friendly opportunities for conductingbusiness over the Internet with telephone companies, Energy Company, tax board and other institutions. Demand for those services influences also the usage rates of Internet banks. Forexample in 2002 in USA, 81867 private individuals submitted electronic tax declarations79727 of them did it through Internet banks and 2140 through tax board's own home page.

(20.3\% of declarations were submitted electronically). This is increasing the benefits of Internetbanks for the consumers and is a win-win situation for the banks and service providers. 
Several studies including Schultz et al. (2001) suggest that security measures that areinconvenient for users may weaken E-Banking prospect, for example because of lack of useracceptance or outright resistance

Here we note some challenges of Electronic banking systems (H. C. Lau \&etal, 2001):

\section{Challenges before system}

Lack of outline plans \& sufficient study to perform new technology, Lack of choose that how perform technology with the highest efficiency, Lack of culture and knowledge of banks about Electronic banking, Lack of engagement of banks management in the system, Lack of management to use experts in IT section, Traditional attitude toward data reengineering, Lack of economical justification and risk to use Electronic banking systems.

\section{- Challenges with performing system}

Weakness of available facilities, Lack of money protection, Lack of special enterprises or their support, ca, gateway institutes such as psps\& VISA, Lack of content \& customers interest

- Challenges after system

Lack of legal rights and electronic justification, People don't like to reveal their financial policies, Lack of motivation and culture training, Lack of trust in users, Lack of electronically security e.g.: E-sing \& PKI

\section{Cost and Fees}

Customer service delivery attributes in the electronic banking industry are important, in view of the fact that online banking, mobile banking and ATM interaction are the main sources of service delivery. Therefore, offering high quality services to satisfy consumers' needs, at lower cost and fees, will be the potential competitive advantage of electronic banking sustainability and growth in the future. At present, studies show that electronic banking has successfully reduced operating and administrative cost and fees (Ahmad, 2011; Migdadi, 2008; Suganthi, 2010 and Bankole et al, 2011) while at the same time research has proven that, cost and fees savings have helped e-based banks offer lower or no service cost/fees (Ahmad, 2008). Cost was once considered as the major competitive priority and a key aspect for the future development in every organisation (Burgess, 1998). Prior research has empirically found a positive relationship between cost/fees and customerservice delivery as a critical factor with the use of electronic banking (Ching et al, 2011 ad Khumbula, 2010).

\section{Challenges in E-banking forDeveloping Countries}

Based on 'best practices' in developed countries, United NationsConference on Trade and Development (UNCTAD) report hasidentified four challenges that developing countries, in general,are expected to overcome to achieve the advantages that ebankinginitiatives can bring about (UNCTAD 2002):

(1) The ability to adopt global technology to local requirements:An adequate level of infrastructure and human capacity buildingare required before developing countries can adopt the globaltechnology for their local requirements.

(2) The ability to strengthen public support for e-finance: Historically,most e-finance initiatives in developing countries havebeen the result of cooperative efforts between the private andpublic sectors.

(3) The ability to create a necessary level of regulatory and institutionalframeworks: The lack of regulatory frameworks, trust,security and privacy standards, high trade barriers, customer andinvestor protections impede progress in implementing e-bankinginitiatives on a larger scale in many developing countries.

(4) The ability to mainstream small and medium scale enterprises(SMEs) towards e-banking: The availability of and access to qualitydata and banking information is required for SMEs in developingcountries to move towards e-banking. Similarly, on-line creditinformation will enhance SME's ability to secure financing.

\section{Status}

The Internet includes all related web-enabling technologies and opentelecommunication networks ranging from direct dial-up, the public World WideWeb, cable, and virtual private networks. (BIS-EBG, 2003) $-\square \square$ Internet banking (ebanking) is defined to include the provision of retail and smallvalue banking products and services through electronic channels as well as largevalue electronic payments and other wholesale banking services deliveredelectronically. (BIS-EBG, 2003)Status in developing countriesDeveloping countries are in catching up in e-banking:

$-\square \square$ The average ebanking penetration for developing countries by the end of 1999 wasclose to 5\% (World Bank Survey, 2001).

$-\square \square$ In Brazil, the number of ebanking users reached 8 million in 2000.

$-\square \square$ In Mexico, the number of ebanking users reached 1.25 million in 2000.

$-\square \square$ In India, over 50 banks are offering online banking services. ICICI Bank's ebankingis very impressing.

$-\square$ E-banking in Korea, Thailand, Malaysia, and Singapore, Hong Kong and Taiwan(China) is thriving. 
$-\square \square$ In Ghana and some other African countries, smart cards based on Visa Horizonproximately technologies are getting started.

\section{Methods}

In Iran, the commencement of electronic banking turns back to 1381-1391. From 2001 thecomprehensive paying system is defined and its operational levels are under construction. By theend of implementation levels all banking operations will be done by the use of electronic system. The comprehensive paying system includes: 1- Shetab system that has been implemented in 2001.

2- SATNA system that has been established in 2006. 3- Paya system. 4 -TABA systems. 5- theproviders of paying services. 6- Sheba System

Internet: Based on a report issuedby a site named InternetWorldStats, Iran stands in 34/9 place in regard of Internet use in themiddle east. Zionist regime has allocated the 74th stand and has won the first place. After that,Emirates stands in 48/9th place, Qatar stands in 42/6th place and Lebanon stands in 39/5th placerespectively. The amount of influence in Turkey is 35 and it stands in 26/5th place that is higherthan the position of Iran.

\section{Cultural obstacles:}

\section{The reasons to lack of electronic banking system in Iran}

Before we go to cultural obstacles it should be mentioned that culture is acquired so the elementsthat are discussed hereunder are due to lack of education and information.These elements include: lack of information among electronic bank users, the resistance ofbeneficiaries toward electronic banking, lack of the culture to use electronic bank system and IT.

In order to study the influence of this element, we can use the statistics provided by central bankand the statistics center of Iran.Based on the declaration of Iran's statistics organization, the population of each province is listedin following:

5 populated provinces of Iran are: Tehran ,RazaviKhorasan, Isfahan, Fars and Khouzestan and onthe other hand Ilam, Semnan, Kohkiluye and Boyer Ahmad, Southern Khorasan and NorthernKhorasan are less in population.

The central bank did not provide statistics regarding the amount of transactions of other bankingmodels like internet transactions and it only provided information about the transactions in ATMsand POS. It seems like other types are not very popular in the country yet. As a result we justdiscuss ATM and POS in this study (until2011/2/19): The result of the study is summarized inbelow table:

\section{Financial obstacles:}

Every alteration requires foundation, support and expertise. The possibility to have suitablefoundations, updated equipments and support groups requires a considerable amount of money. Infundamental changes of the society such as electronic banking this issue is of even moreimportance. Lack of investment in the field of telecommunication, expenses regarding webconnection, satellite expenses, the expenses for up grading webs are some examples in thisregard.

The average speed of Internet is $128 \mathrm{~Kb}$ per second and it costs 20000 Tomans monthly. Aboutusing ATM and POS machines it should be said that the banks keep receiving commissions.Telecommunication center is not faced with serious financial problems in this regard.

\section{Technical obstacles:}

Electronic banking is dependant to updated and useful technology. Lots of are required in this regard at the same time like telecommunication, information technology, etc. The influencing factors on electronic banking are: access to web, internet speed, ISP centers,number and width of internet bands, lack of IT and electronic banking experts, lack of quality, ICIexpansion, disqualified electronic banking services, etc.

Based on the ranking of countries in respect of personal internet speed in first half of 2010, 152countries were studied and Iran has the 144th place after Venezuela, Nigeria, Bolivia, Iraq,Prague, Turkey and kayaks with the speed of 0.61 MB per second.The width of imported international internet band: $1705 \mathrm{Mbps}$, The width of exportedinternational internet band: $1705 \mathrm{Mbps}$, number ISP: $\mathrm{t} 1370$, the capacity of information transfer: 106000 MB, Fiber optics: $56000 \mathrm{Km}$.About the speed of problem solving no statistics have been issued.

About the number of IT-EB experts it should be mentioned that from 1381 the universityacceptance in the field of IT MA and BA is started and in the field of EB there's no officialtraining course and the problem of IT graduates is lack of experience due to its new nature.The telecommunication center is expected to provide the needs of banks but no statistics have 
been delivered in this regard. But based on the issued statistics by central bank about thetransactions it can be understood that the banks are improving their electronic bank services allover the country and it's a sign of telecommunication services to the banks.

\section{Conclusion and Recommendations}

Many of the Banks that are piling onto the electronic banking may totally misunderstand what this mediumis all about. Apparently, banks cannot succeed in exploiting electronic banking unless the right electronicbanking infrastructure and development are in place to meet the demands of the users. Today, the bankingindustry is gradually moving from a product and sales philosophy to a new marketing philosophy. Thus, e-basebanks have emphasised a better understanding of customer's needs and wants and then translated them into thecapability to give customers what they really need and want. Electronic banking determines what can be offeredto customers, but only customers determine which of those technologies will be accepted. Customer servicedelivery may increase based on the want, need, times, power of buying, and status. Therefore, the key to successin electronic banking lies in knowing the customers.

$-\square$ Internet penetration is a major factor for the growth of E-Banking. A research by OECDindicated that there is a strong positive correlation between Internet usage and E-Bankingusage. The trend is usually logarithmic and the take off phase of Internet banking needs atleast 30\% Internet usage among the population (Christiansen, 2001). However, Internetpenetration alone does not guarantee online banking penetration. In this situation, likeIran, companies can give incentives, subsidizing the surfing cost, free training, multipleaccess facility (web, telephone, ATM etc.), motivation programs to the user and thepopulation as a whole.

The research results show that by adopting e-banking banks expose themselves to operational and reputational risks. If e-banking is to be successful in Iran, the services must be carefully integrated into the traditional system so as to avoid causing unnecessary disruptions to any services offered by the bank. The study also concludes that fraud poses the biggest challenge to commercial banks as they adopt electronic delivery channels. The cost of implementation for e-banking can be too high for commercial banks as it largely requires infrastructural development, training of staff members and sometimes even outsourcing some of the electronic banking services. The adoption of e-banking requires the incorporation of sound risk management principles for it to be effective. Each financial institution should apply guidelines based on its scope and level of sophistication. Typically, electronic banking amplifies the scale of exposure of banks to traditional risks, such as transaction, strategic, reputational, and compliance risks, among others. Therefore, banks should ensure that there are adequate policies and procedures relating to risk management which involve an element of a segregation of duties; an effective security program has been implemented with appropriate communication on policy, procedures, and practices, with the necessary support from the bank's directorate.

-WAP is very important for the viable introduction e-banking. So, steps must be undertaken to introduce, develop and extend the WAP.

-E-Banks must try to expand their network as soon as possible. Because most of the cases customers uses E-Banking facility to pay bills, shopping etc. As more and more third party will involve in the network, they could attack more customers.

National as well as the international communication must be extended.

e-banking technology is mature, dependable, available and viable, so arrangement must be made for the introduction of the latest ICT technology.

e-banking service must be convenient, uncomplicated, quick, easy available and user friendly.

e-banking experts are available, however with the growing needs more experts must be there. So, respective education and training institutes must be established following the growing needs of the market.

Clients are aware of e-banking services; they do not resist the introduction of e-banking. However, it would not harm if campaign is set to popularize the e-banking.

Market size seems to be important for e-banking. However, it must not be very big for the success of the e-banking. It seems to be modern art of banking.

Unemployment is also very much detrimental to e-banking. Naturally, enhancing literacy rate would create more enabling environment for ebanking.

No rhetoric but effective, sincere and practical efforts from the side of the government are expected for successful and timely introduction of e-banking.

Government should create a congenial environment for this sector, and provide adequate training and technological support to develop the manpower.

Banks should have their own Strategic plans for e-banking.

Banks should have adequate research and technological background in this regard. 


\section{Reference}

[1]. A.Gudarzi, h.zobida(1387), review of effect of E.B development on efficiency of Iran banks benificery,

[2]. AlirezaMoghali (1386), "The acceptance of electronic banking in customers in Shiraz" ,management

[3]. Analysis, September.

[4]. Beckier, M.M., Flur, D.K. and Singham, S.J. (2000) 'A future for bricks and mortar',McKinseyQuarterly, Vol. 3, pp.78-85.

[5]. BIS 2003, Management and supervision of cross-border electronic banking activities.

[6]. conference of banking function interview to achieve the goal of economy, social and cultural development in

[7]. factors, research magazine of humen\& social science, 7 th year, number 27.

[8]. Feinman, T., Goldman, D., Wang, R. and Cooper, N. (1999) Security Basics: A Whitepaper,

[9]. Financial Services Security Lab Background (2001) 'Security issues and threats', BankingIndustryTechnology Secretariat, http://www.bitsinfo.org/ppindustry.

[10]. Franco, S. C., Klein, T. (1999) Online Banking Report, Piper Jaffray Equity Research,

[11]. Furash, E.E. (1994) 'Payments system under siege: customers want information along withmonetary transfers, non-banks are providing it', ABA Banking Journal, June, Vol. 86,

[12]. Furst, K., Lang, W.W. and Nolle, D. (2000) 'Internet banking: developments and prospects', Working Paper 2000-9, Office of the Comptroller of the Currency, Economic and Policy

[13]. Gefen, D and Straub, DW 1997, 'Gender differences in the perception and use of e-mail: an extension to the technology acceptance model', MIS Quarterly, pp.389-399.

[14]. Hogarth, JM, Kolodinsky, J and Gabor, T 2008, 'Consumer Payment Choices: Paper, Plastics or Electrons', International Journal of Electronic Banking” Vol. 1 No. 1 pp 16 Kamakodi, N \& Khan, BA 2008, 'Looking beyond technology: a study of e- banking channel acceptance by Indian customers', International Journal of Electronic Banking, Vol. 1, No. 1, pp.73-94.

[15]. Gulatti, R. and Garino, J. (2000) 'Get the right mix of brick and clicks', Harvard BusinessReview,May-June, pp.107-114.

[16]. Hackett, J. (2000) 'Gauging prospects of net mortgages: the health of the online bankingsectormay be the canary in the mineshaft', Mortgage Technology, March, Vol. 28.

[17]. Halperin, K. (2001) 'Balancing act', Company Business and Marketing, February.

[18]. Hitt, L.M. and Frei, F.X. (2002) 'Do better customers utilize electronic distribution channels?Thecase of PC banking', Management Science, Vol. 48, No. 6, pp.732-748.

[19]. http://www .pwc.com.

[20]. Hughes, T. (2003) 'Marketing challenges in e-banking standalone or integrated?', Journal of

[21]. Iran, p.120-139.

[22]. Kaynak, E. and Harcar, T.D. (2005) 'Consumer value creation in mobile banking services',International Journal of Technology Marketing, Vol. 1, No. 1, pp.62-78.

[23]. Klinkerman, S. (2000) 'Bridging two worlds: management strategies in transformingbanking companies to compete in ecommerce', Banking Strategies, September, p.26.

[24]. Klinkerman, S. (2001) 'Incentives revisited', Banking Strategies, p.64.

[25]. Lee, E, Lee, J and Schumann, D 2002. 'The influence of communication source and mode on consumer adoption of technological innovations', Journal of Consumer Affairs, Vol. 36, No. 1, pp.1-28. Lee, E and Lee, J 2000 'Haven't adopted electronic financial services yet? The acceptance and diffusion of electronic banking technologies', Financial Counselling and Planning, Vol. 11, No. 1, pp. 49-60.

[26]. M.R.Hamidizadeh, m, gharechi, A.abdol-baghi(1386), review of E.B December challenges and problems

[27]. magazine of Iran's economic result, 10th year; number 35; 1387 summer p.111-140.

[28]. Marketing Management, Vol. 19, pp.1067-1085.

[29]. No. 6, p.55.

[30]. Nsouli, S.M.; and Schaechter, A. (September, 2002), Challenges of the"E-Banking Revolution", Finance \& Development, Vol. 39, No. 3.

[31]. of Iran 1404, knowledge and development magazine 16th year, number 26.

[32]. Orr, B. (2004) E-Banking job one: Give customers a good ride. ABA Banking Journal, Vol. 96, Iss. 5, pp 56-57.

[33]. P. Kasturiratna, "Internet Only Banking”, 23rd National IT Conference C 14. olombo, 9th July 2004.

[34]. P.H.Amadeh, m. Jafarpor(1388), E.B development problem and strategies in the frame of outline document

[35]. Putrevu, S 2002 'Exploring the origins and information processing differences between men and women: implications for advertisers', Academy of Marketing Science Review, Vol. 6, Viewed 8th December 2010

[36]. Rao, S. (2004) 'Building inter-firm relationships online: perspectives from the Australian internetbanking industry', International Journal of Internet Marketing and Advertising, Vol. 1, No. 4,pp.371-387.

[37]. S. manuchehri(1384), review of banking result in performing electronic banking; set of essays in first

[38]. science of Iran Journal, No.7

[39]. Shah, M. H., Branganza A., Khan S., and Xu M. (2009) “A Survey of Critical Success Factors in e-Banking” 0.1.1.108.6368.pdf (last accessed on 18 June 2012)

[40]. Stamoulis, D S. (2000), "How Banks Fit in an Internet Commerce Business Activities Model," Journal of Internet Banking and Commerce, June, 5(1); Available [online] at http://www.arraydev.com/commerce/JIBC/articles.htm; Accessed on 7January 2001.

[41]. Sweeney, A. and Morrison, M. (2004) 'Clicks vs. bricks: internet-facilitated relationships infinancial services', International Journal of Internet Marketing and Advertising, Vol. 1, No.

[42]. Zeithaml, VA and Gilly, MC 1987 Characteristics affecting the acceptance of retailing technologies: a comparison of elderly and non-elderly consumers', Journal of Retailing, Vol. 63, No. 1, pp.49-68. 